\title{
RECORD BOOK
}

\section{Florida 4-H Dairy Record Book}

Name:

Parent's Name:

Mailing Address:

\begin{tabular}{|l|l|l|}
\hline \multicolumn{2}{|l|}{ City: } & State: \\
\hline Age: & Jr., Int., Sr.: & Date of Birth (mm/dd/yyyy): \\
\hline Grade in School: & & School Name: \\
\hline
\end{tabular}

Name of 4-H Club:

Name of 4-H Club Leader:

Name of 4-H Agent:

County:

I hereby certify that, as the owner of this project, I have personally been responsible for the care of this (these) animal(s), kept records on this project, and completed this record book.

Member's Signature

Date

I/We, the parent(s), certify that my/our child has completed this project and this record book.

Parent/Guardian Signature

Date

I certify that the above-named individual is an active member of the 4-H Club in County. I verify that this record book has been completed by the student and is an accurate representation of the project.

4-H Club Leader Signature

Date

UF/IFAS Extension 4-H Agent Signature

Date

Written by: Karen Hamilton, Chris Decubellis, Chris Holcomb, and Sarah Hensley

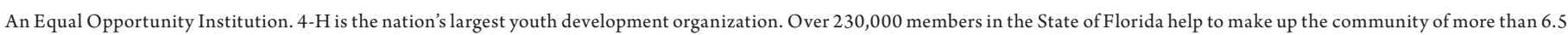

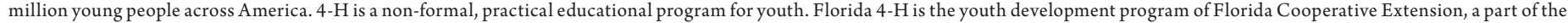
University of Florida/IFAS. 


\section{Table of Contents}

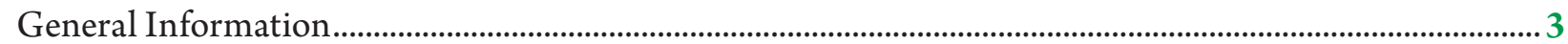

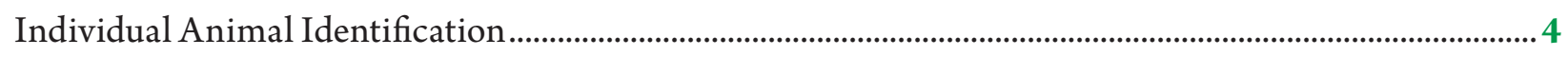

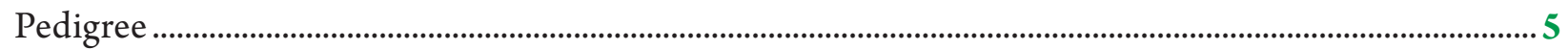

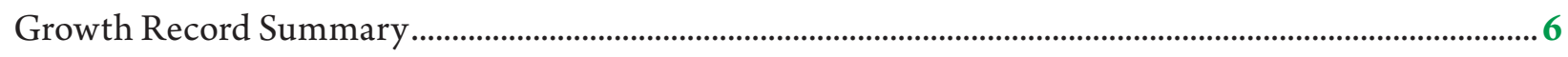

Dairy Heifer Growth Chart ................................................................................................................................

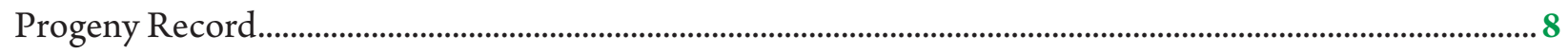

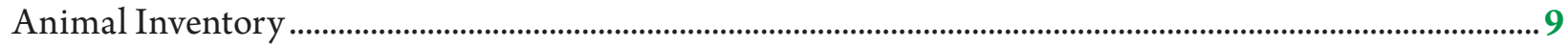

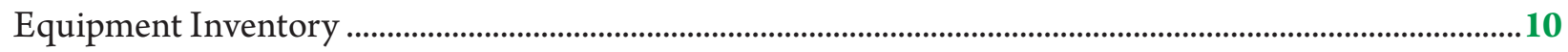

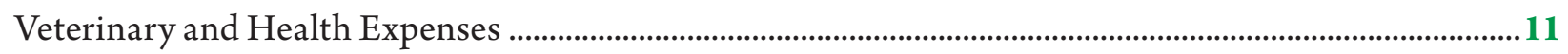

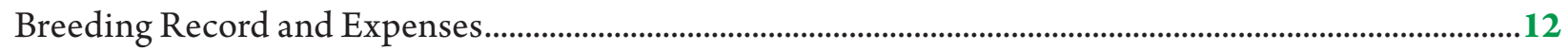

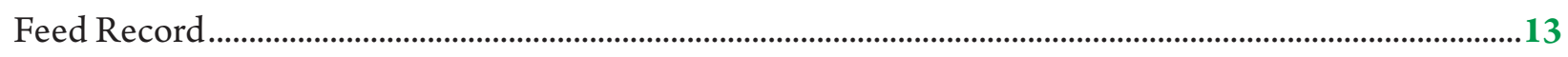

Ration Record ……...........................................................................................................................................14

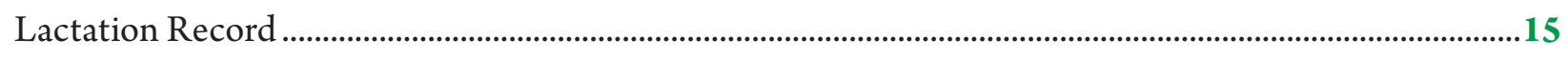

Show Receipts and Expenses ............................................................................................................................ 16

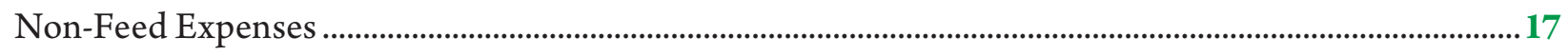

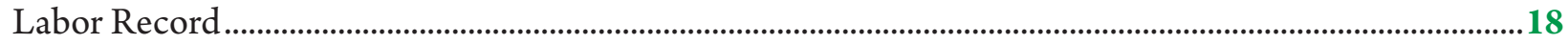

Animals Sold ………........................................................................................................................................19

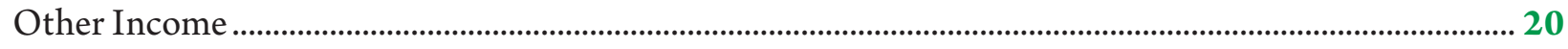

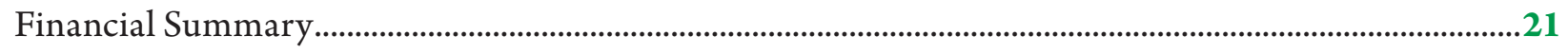

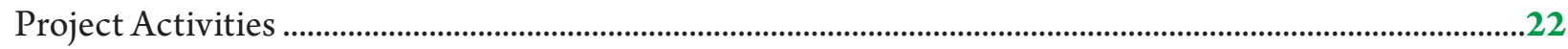

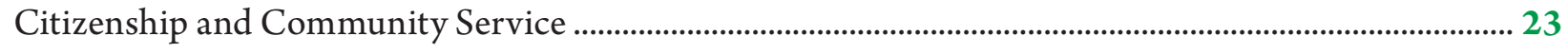

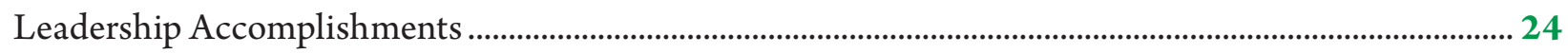

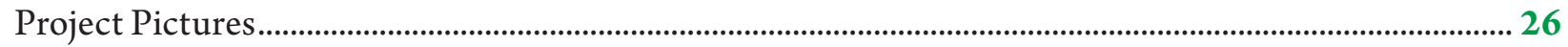

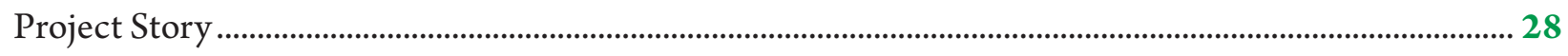

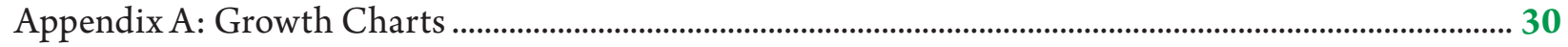

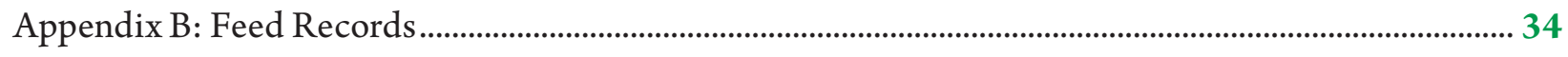

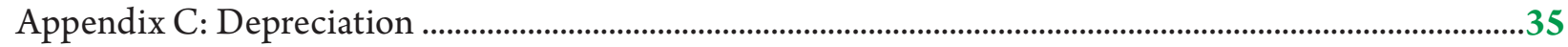




\section{General Information}

\section{Your 4-H Dairy Project}

This project record will help you and others see what you have learned about your dairy project animal(s). It will also serve as a way to teach others how to develop an outstanding project.

Primary Objectives of the Dairy Project:

- Become aware of the scope and economic significance of the dairy industry.

- Acquire skills in dairy production through ownership and care of dairy animals.

- Learn marketing, processing, distribution, and use of dairy products.

- Learn and practice principles of cleanliness and sanitation as applied to the production and care of dairy products.

- Learn the nutritive value of dairy products and promote their use.

- Appreciate contributions and applications of scientific research to the dairy industry.

- Develop sportsmanship, cooperation, decision-making, and public speaking skills through participation in demonstrations, tours, judging, and/or exhibits.

To find additional resources to help you with your project, visit http://www.4-h.org/resource-library/curriculum/.

The Dairy Cattle Skills for Life series is a set of three levels of project guides that are filled with activities and information that can help you increase your knowledge of dairy cattle. These include Cowabunga!, Mooving Ahead, and Rising to the Top.

Also visit http://articles.extension.org/mediawiki/files/1/13/Monitoring_Dairy_Heifer_Growth.pdf for Monitoring Dairy Heifer Growth, an excellent publication from Penn State University.

The Dairy Goat Skills for Life series is a set of three levels of project guides that are filled with activities and information that can help you increase your knowledge of dairy goats. These include Getting Your Goat, Stepping Out, and Showing the Way.

\section{***Note: Make additional copies of pages as you need them***}




\section{Individual Animal Identification}

Breed:

Birthdate:

Tattoo:

Registration Number:

Ear Tag Number:

Date Acquired:

Name of Breeder or Previous Owner:

Address of Breeder or Previous Owner:

Pictures of Dairy Animal (Insert photos or outline drawings of your dairy animal.)

Right Side Photo

Frontal Photo

Left Side Photo

Make copies of this page as necessary. 


\section{Pedigree}

Enter the name and registration number. Make copies of this page as necessary.
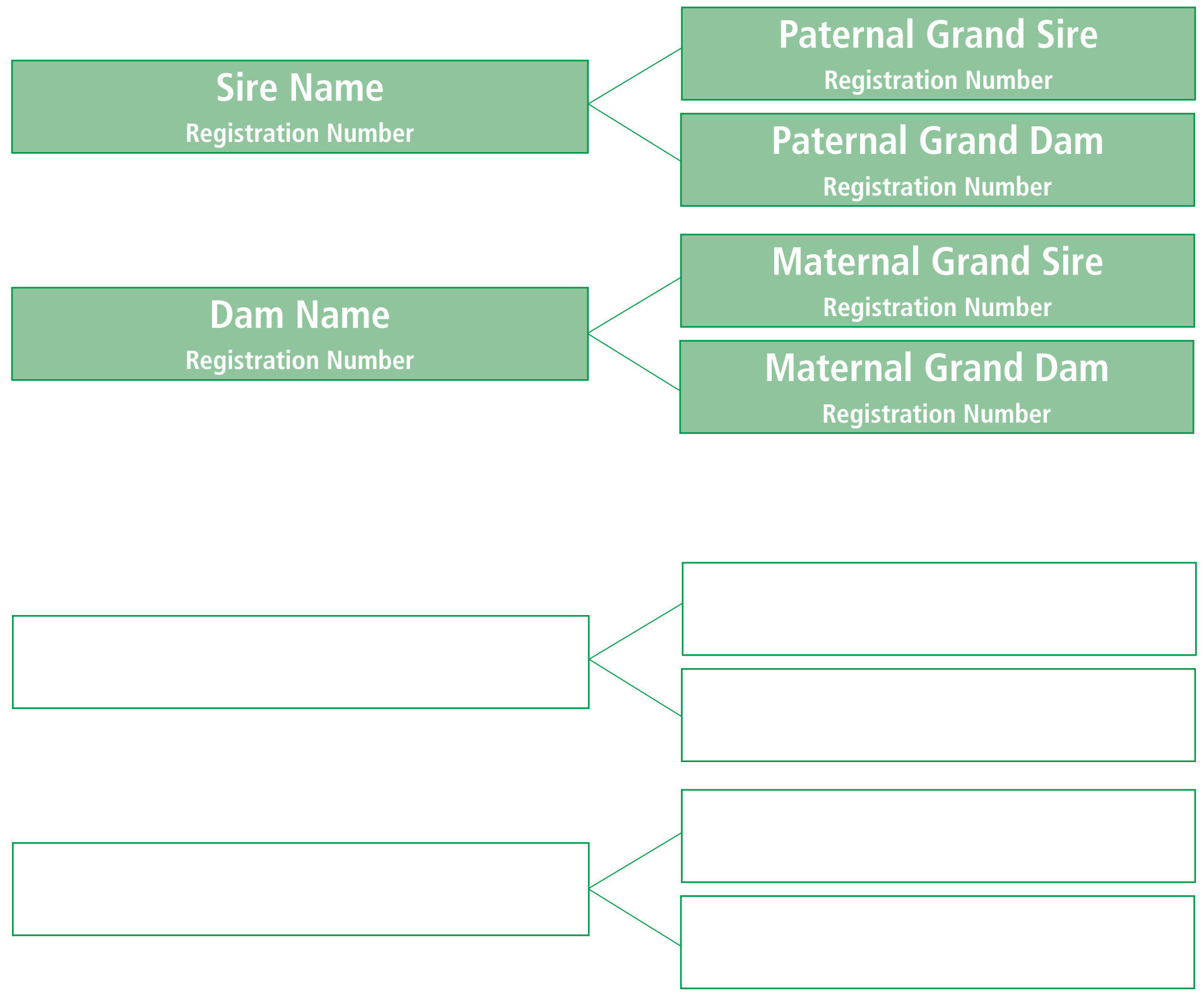


\section{Growth Record Summary}

Fill this out monthly to keep track of your animal's growth; use growth charts (Appendix A) for the appropriate breed to compare your animal's breed recommendations.

\begin{tabular}{|c|c|c|c|}
\hline $\begin{array}{c}\text { Age } \\
\text { (months) }\end{array}$ & Weight (pounds) & Height at Withers (inches) & Heart Girth (inches) \\
\hline 1 & & & \\
\hline 2 & & & \\
\hline 3 & & & \\
\hline 4 & & & \\
\hline 5 & & & \\
\hline 6 & & & \\
\hline 7 & & & \\
\hline 8 & & & \\
\hline 9 & & & \\
\hline 10 & & & \\
\hline 11 & & & \\
\hline 12 & & & \\
\hline 13 & & & \\
\hline 14 & & & \\
\hline 15 & & & \\
\hline 16 & & & \\
\hline 17 & & & \\
\hline 18 & & & \\
\hline 19 & & & \\
\hline 20 & & & \\
\hline 21 & & & \\
\hline 22 & & & \\
\hline 23 & & & \\
\hline 24 & & & \\
\hline
\end{tabular}




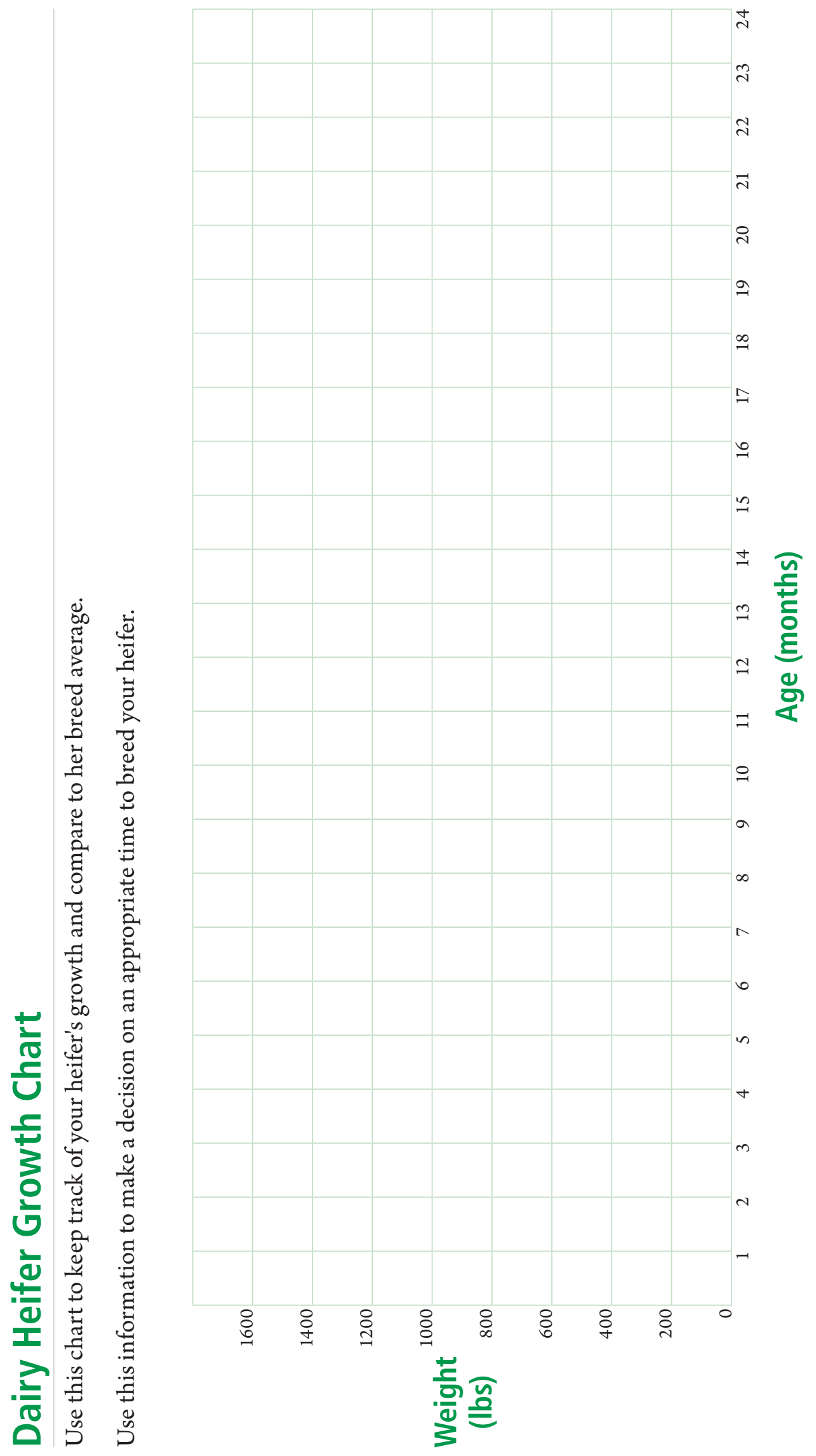




\section{Progeny Record}

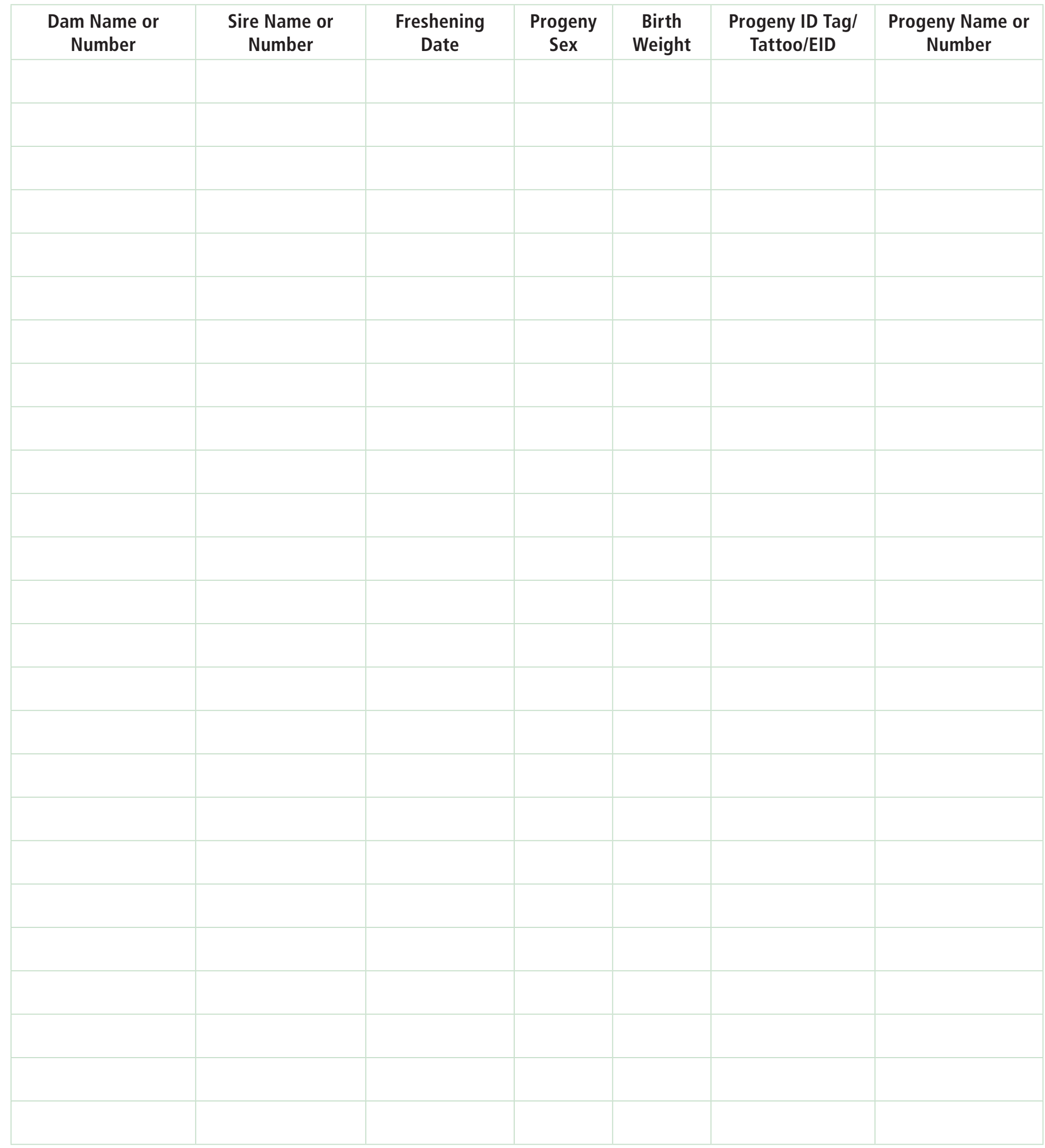




\section{Animal Inventory}

\begin{tabular}{|c|c|c|c|c|c|c|c|}
\hline Animal Name or Number & Sex & Birthdate & Breed & $\begin{array}{l}\text { Beginning } \\
\text { Value }\end{array}$ & $\begin{array}{l}\text { Ending } \\
\text { Value }\end{array}$ & Comments & $\begin{array}{c}\text { Change in } \\
\text { Value }\end{array}$ \\
\hline & & & & & & & $\$$ \\
\hline & & & & & & & $\$$ \\
\hline & & & & & & & $\$$ \\
\hline & & & & & & & $\$$ \\
\hline & & & & & & & $\$$ \\
\hline & & & & & & & $\$$ \\
\hline & & & & & & & $\$$ \\
\hline & & & & & & & $\$$ \\
\hline & & & & & & & $\$$ \\
\hline & & & & & & & $\$$ \\
\hline & & & & & & & $\$$ \\
\hline & & & & & & & $\$$ \\
\hline & & & & & & & $\$$ \\
\hline & & & & & & & $\$$ \\
\hline & & & & & & & $\$$ \\
\hline & & & & & & & $\$$ \\
\hline & & & & & & & $\$$ \\
\hline & & & & & & & $\$$ \\
\hline \multicolumn{4}{|l|}{ Totals } & $\$$ & $\$$ & & $\$$ \\
\hline
\end{tabular}

- To calculate the Change in Value, subtract the Beginning Value from the Ending Value.

- To calculate the Total Beginning Value, add all the numbers in the Beginning Value column.

- To calculate the Total Ending Value, add all the numbers in the Ending Value column.

- To calculate the Total Change in Value, add all the numbers in the Change in Value column.

- Animals that are purchased during the project will be recorded as a non-feed expense.

- The beginning inventory value will be blank on this page.

- Enter the ending value for all animals in the project at the end of the year.

- Note born, purchased, sold, or deceased animals in the Comments column. 


\section{Equipment Inventory}

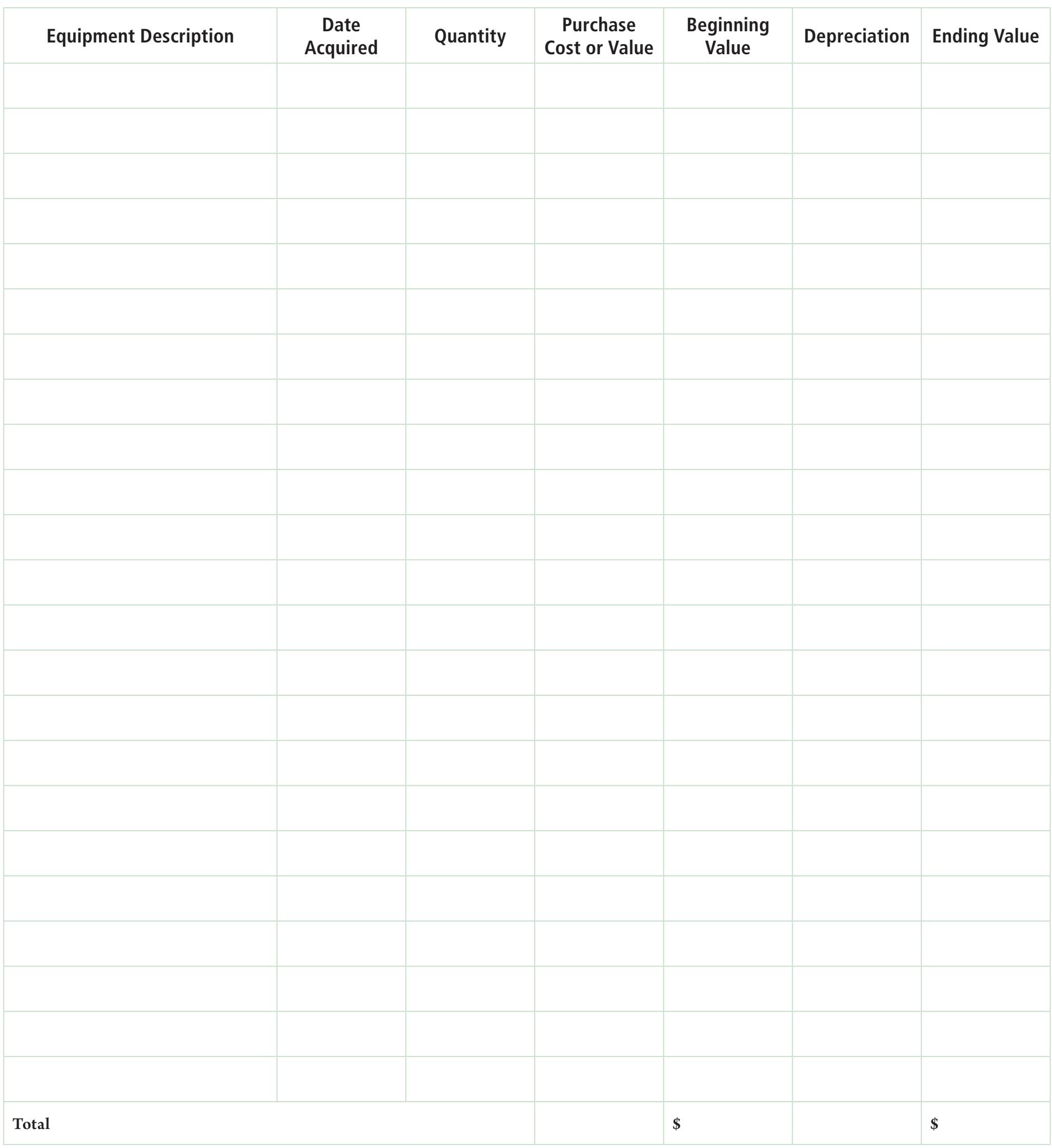

- To calculate the total, add all the values that correspond to that column.

- Refer to Appendix C for information on Depreciation. 


\section{Veterinary and Health Expenses}

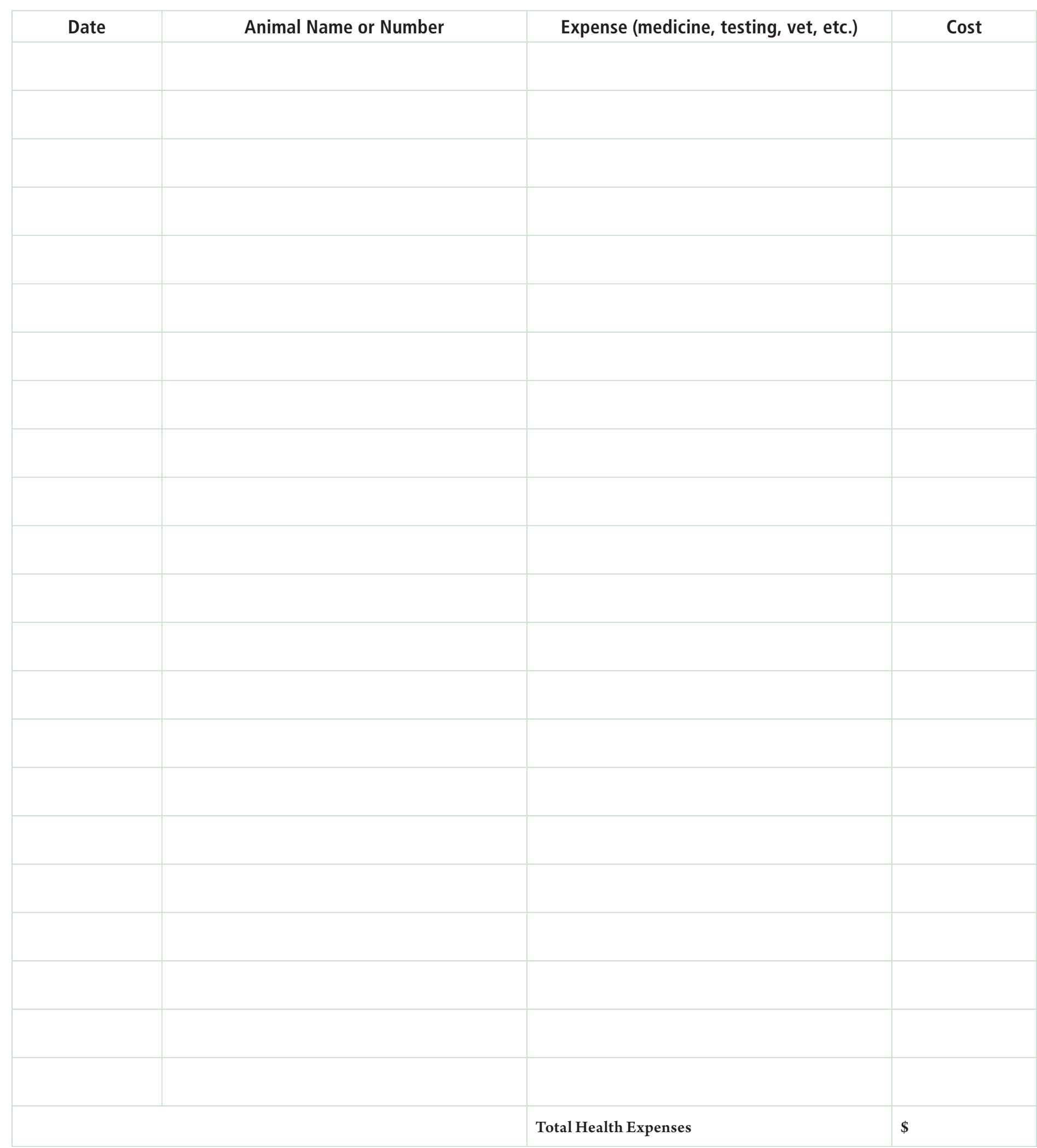

To calculate the total, add all the values that correspond to the Costs column. 


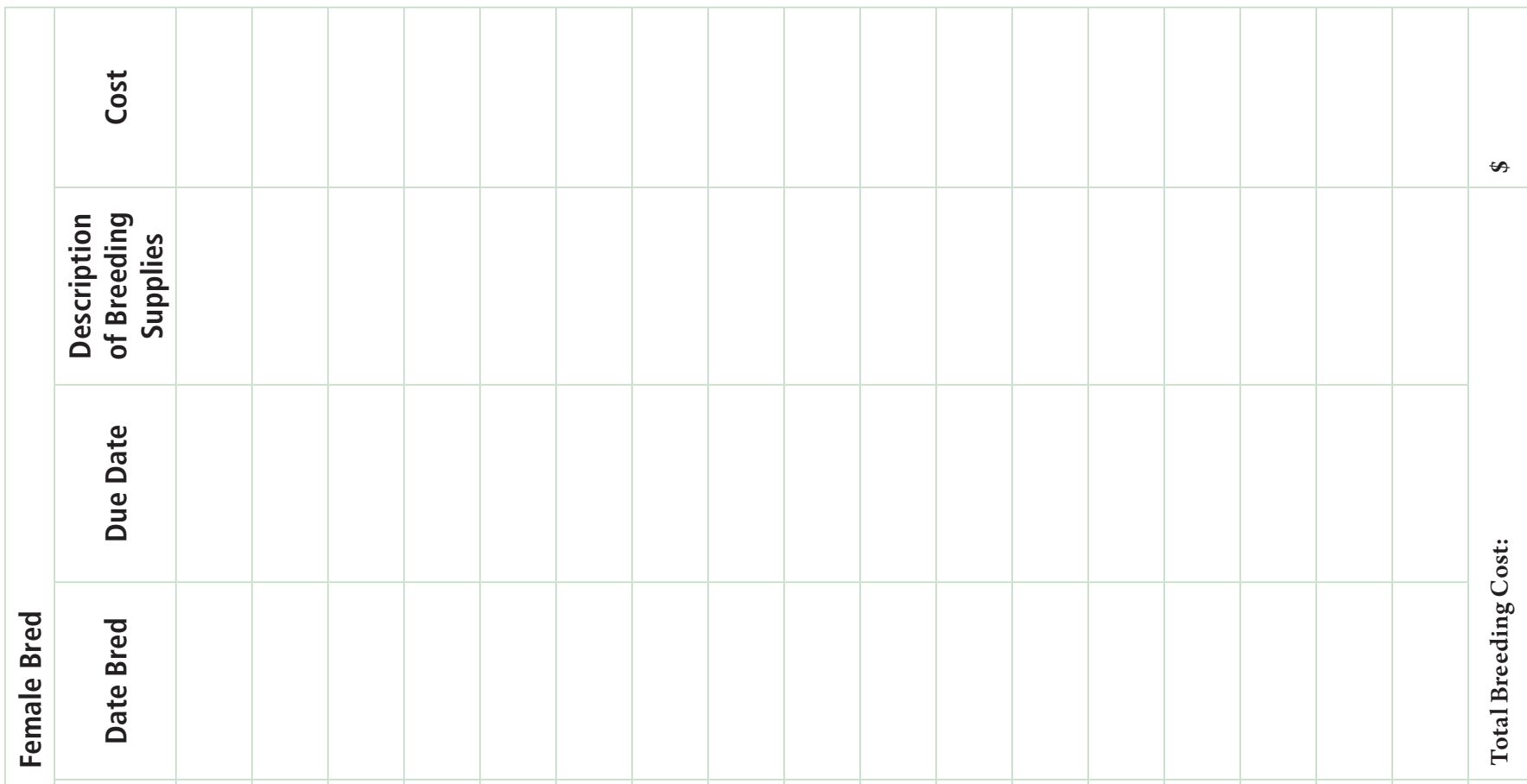

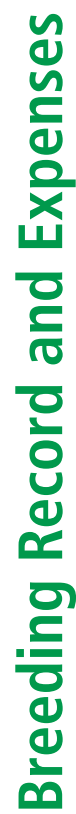




\section{Feed Record}

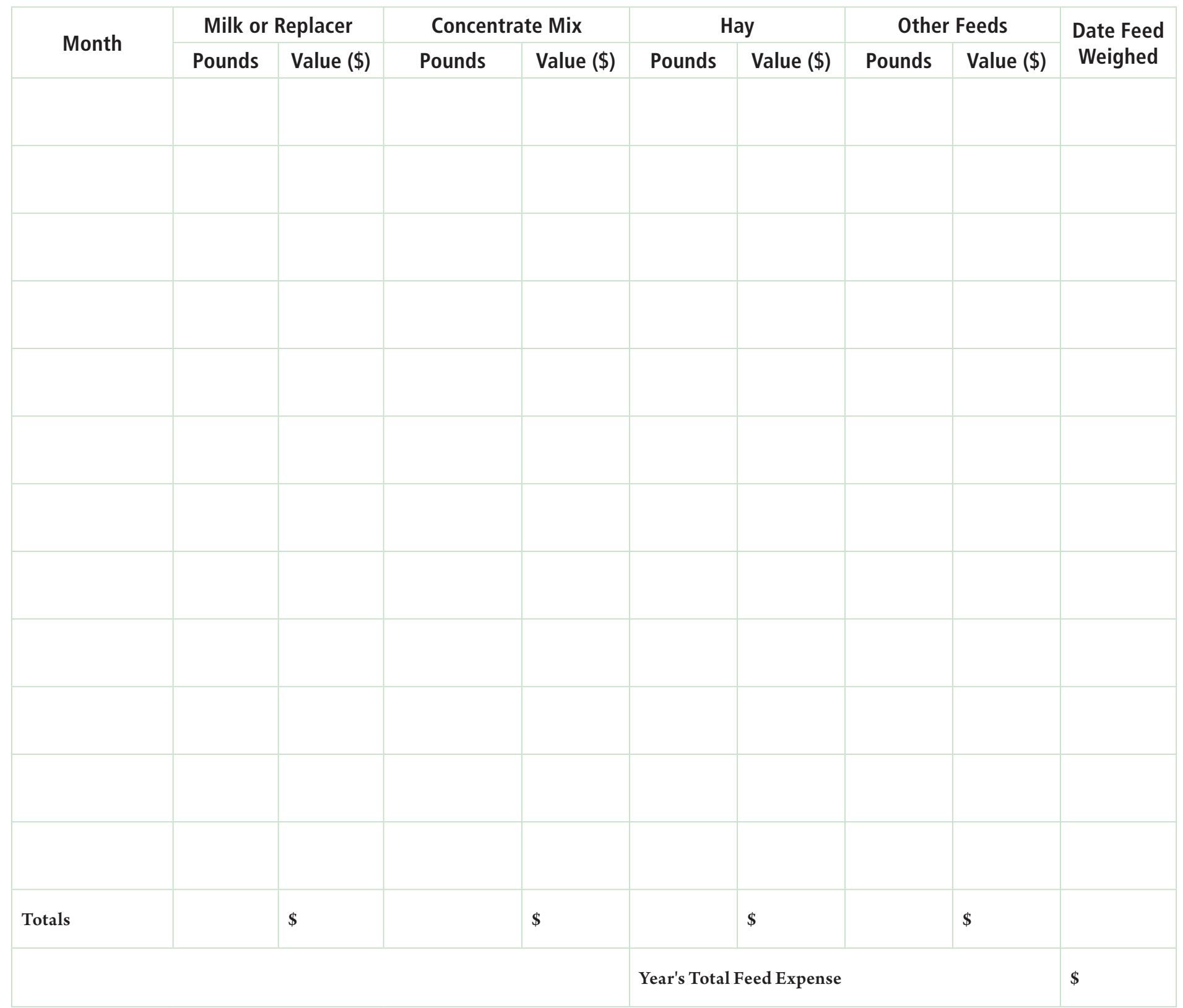

To calculate the total, add all the values that correspond to that column. 


\section{Ration Record}

Refer to your feed label for the information to complete this page.

\section{Milk or Milk Replacer}

\% Protein:

\% Fat:

Main Ingredient:

Medicated: Yes No

Cost per Pound: $\$$

\section{Feed (Concentrate Mix)}

$\%$ Protein:

\% Fat:

Main Ingredient:

Medicated: Yes No

Cost per Pound: $\$$

Juniors: Complete one Feed Records page for all animals by month.

For cows kept at a dairy, write the exchange value of milk for feed.

Intermediates: Complete one Feed Records page per animal group (Calves, Heifers, Cows).

For cows kept at a dairy, write the exchange value of milk for feed.

Seniors: Complete one Feed Records page per animal group (Calves, Heifers, Cows).

For cows kept at a dairy, determine average feed values.

Weigh feed one day each month. Calculate pounds consumed and total value of feed consumed per month.

Refer to Appendix B to complete Feed Records. 


\section{Lactation Record}

Animal Name or Number:

Registration or Ear Tag Number:

Breed:

Date of Birth:

Freshening Date:

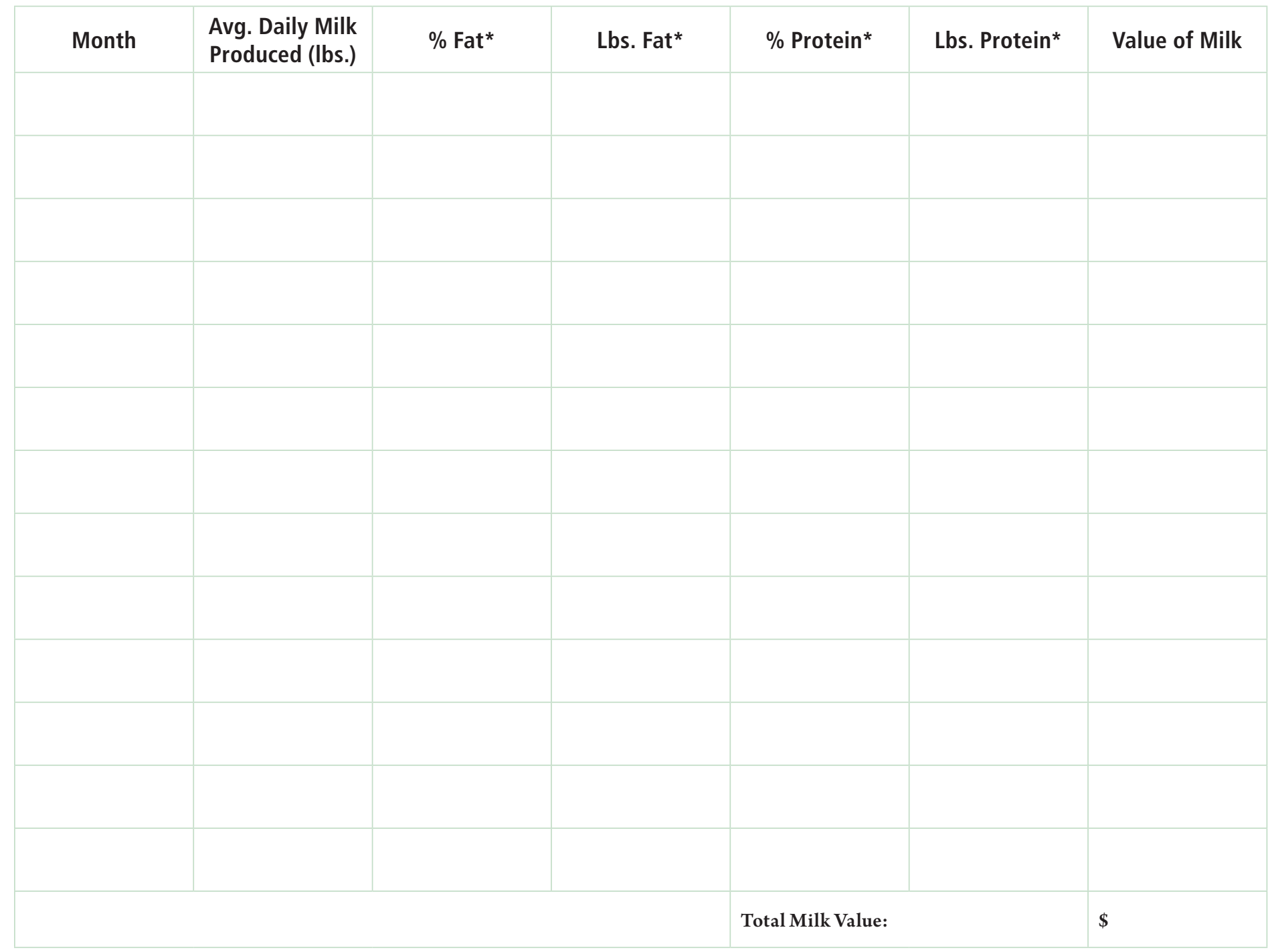

What was Florida's average milk price for the most recent year (look up on the internet)? \$

1. To calculate the total, add all the values that correspond to the Value of Milk column.

2.Make copies of this page as needed.

* Not required. Only fill in if information is available from the dairy. 


\section{Show Receipts and Expenses}

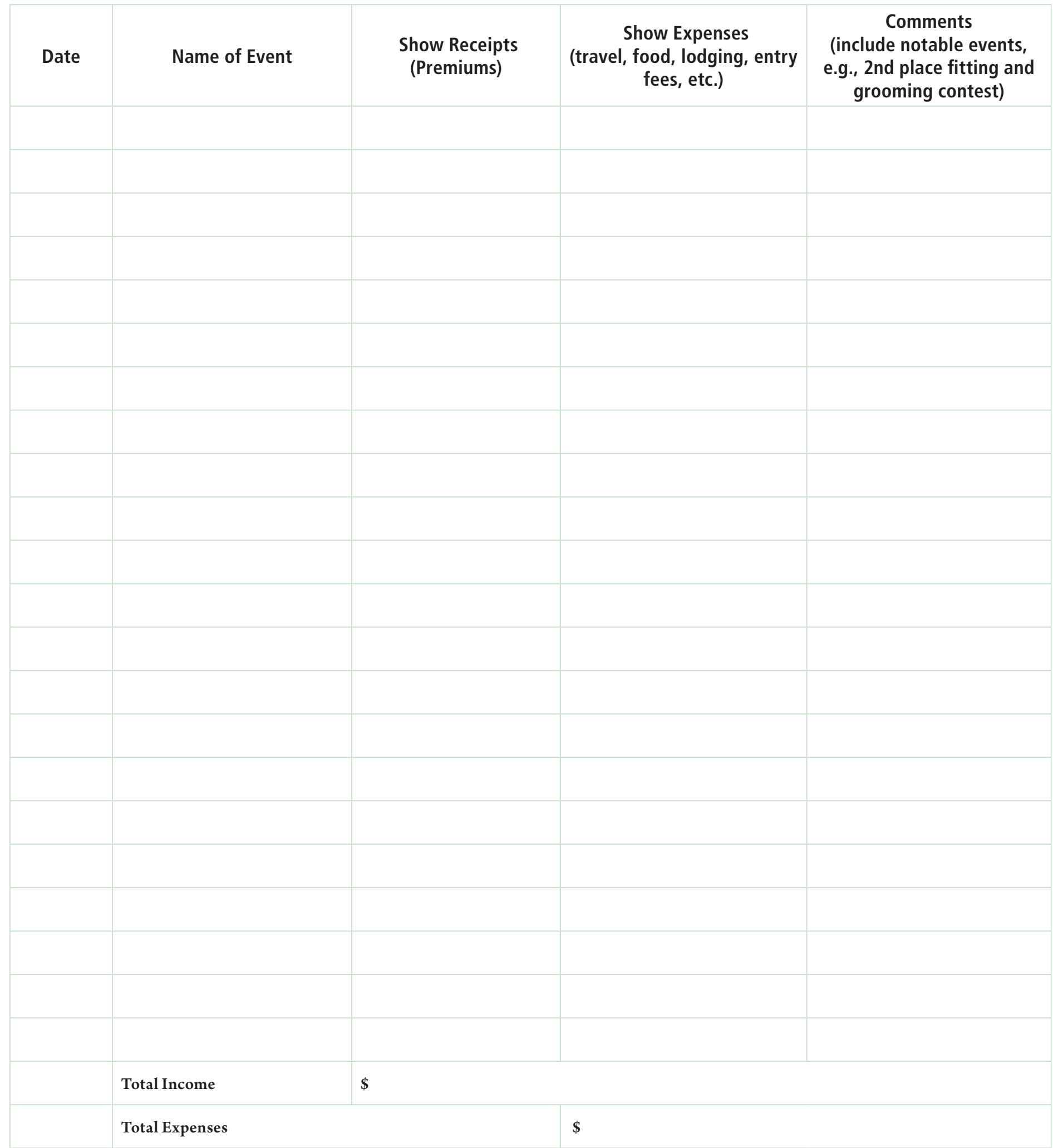

To calculate the total, add all the values that correspond to that column. 


\section{Non-Feed Expenses}

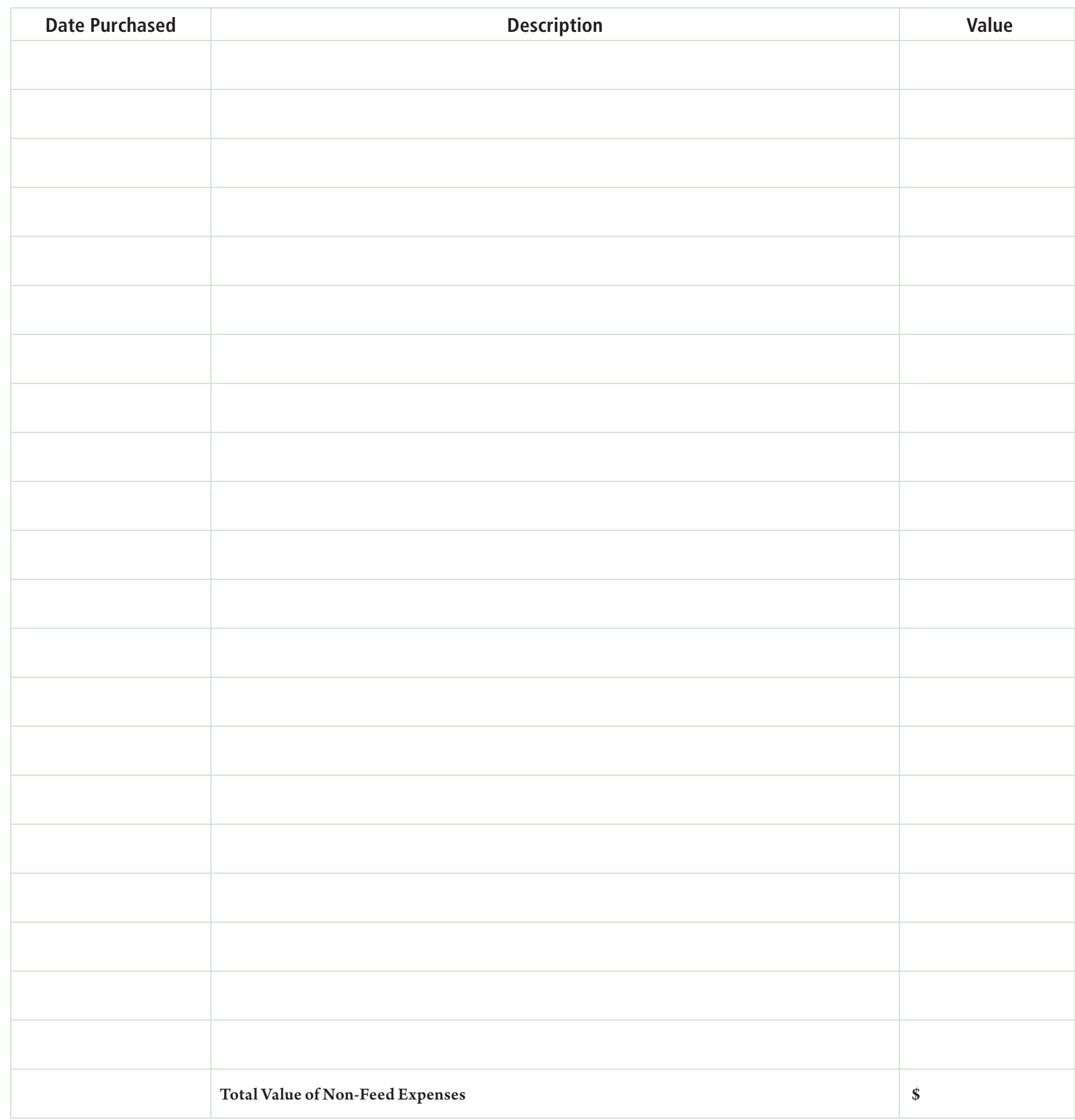

- To calculate the total, add all the values that correspond to the Value column.

- Include all expenses NOT already reported in another record. This should include animals purchased during the project year and other expendable items. 


\section{Labor Record}

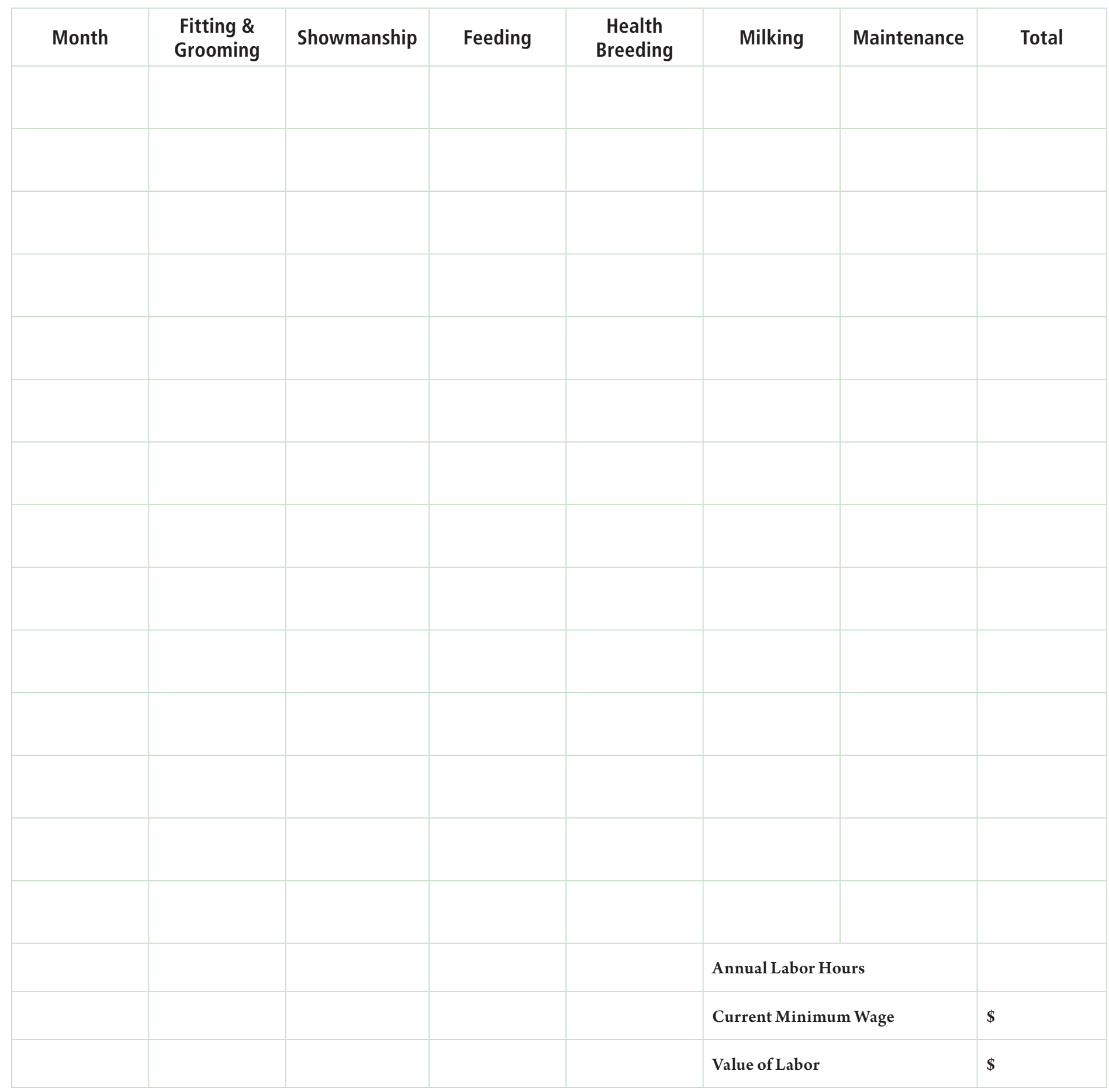

- To calculate the total, add all the values of the row that corresponds to that month.

- To calculate Annual Labor Hours, add all the values in the Total column.

- Include an estimate of the time spent each month on each of the labor activities listed. 


\section{Animals Sold}

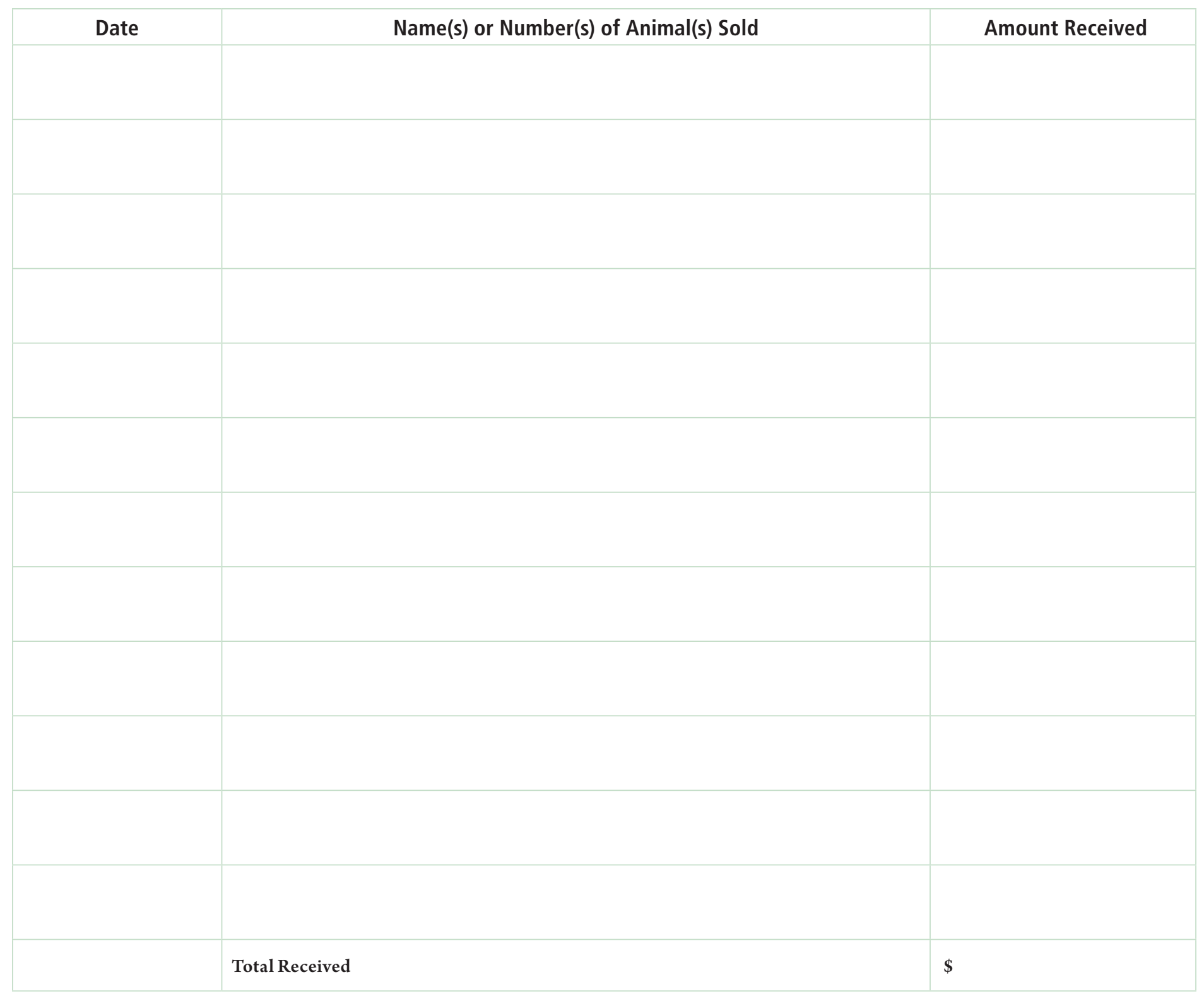

- To calculate the Total Received, add all the values that correspond to the Amount Received column.

- Animals sold should have a value of 0 on your ending inventory. 


\section{Other Income}

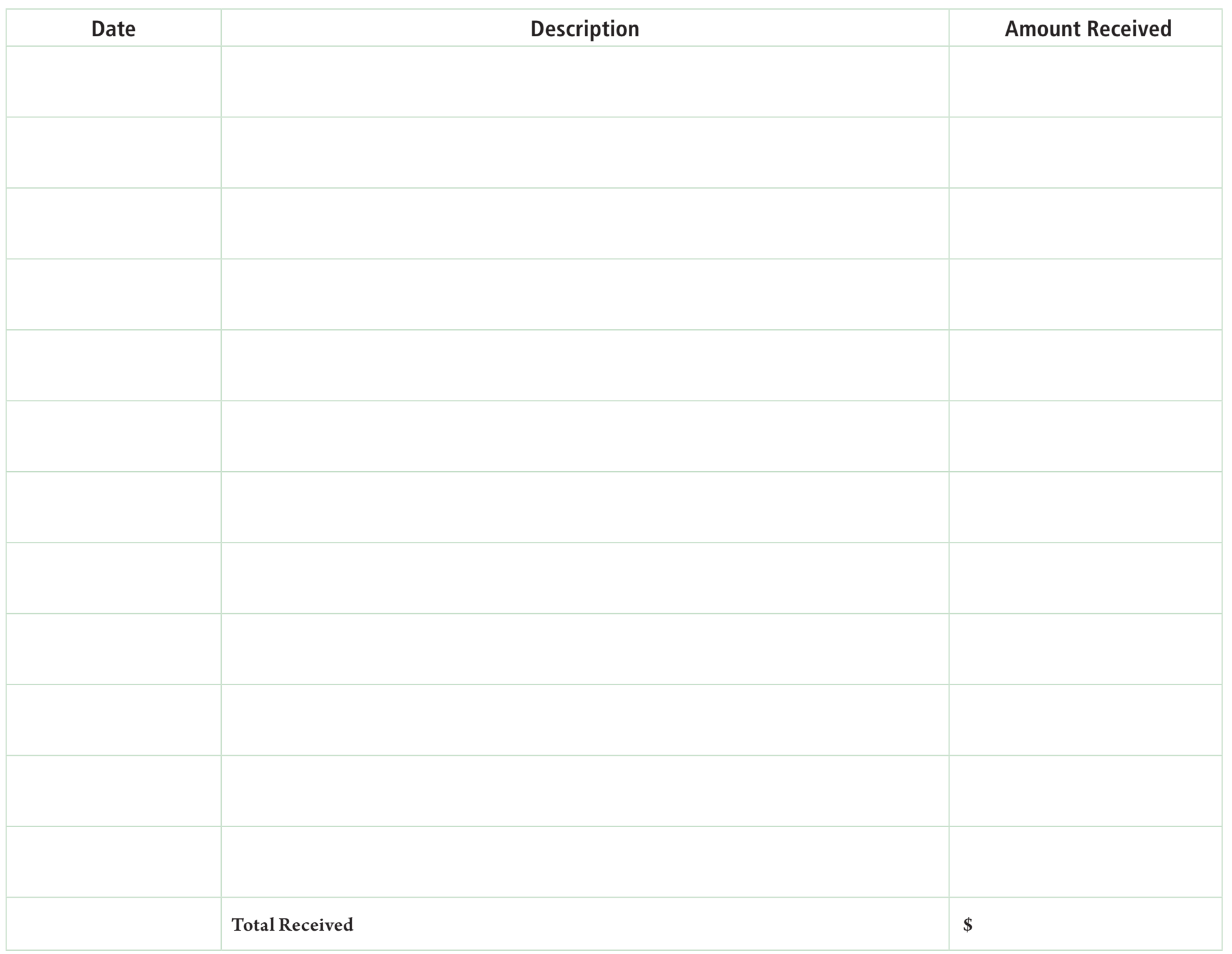

- To calculate the Total Received, add all the values that correspond to the Amount Received column.

- Record any money given to you to support your project by sponsors, parents, etc. 


\section{Financial Summary}

\section{Expenses}

Beginning Animal Inventory:

Beginning Equipment Inventory:

Veterinary and Health Costs:

Breeding Costs:

Feed Costs for ALL Animals:

Show Expenses:

Non-Feed Expenses:

Total Expenses:

\section{Receipts}

Ending Animal Inventory:

Ending Equipment Inventory:

Show Receipts:

Value of Milk Produced:

Value of Animals Sold:

Other Income:

Total Receipts:

Profit/Loss:

Total Receipts - Total Expenses = 


\section{Project Activities}

\begin{tabular}{|c|c|c|c|c|}
\hline Date & Activity & Level & $\begin{array}{l}\text { Number of Times } \\
\text { Attended }\end{array}$ & $\begin{array}{c}\text { Comments } \\
\text { (Ranking, Placing, Accomplishment) }\end{array}$ \\
\hline & & & & \\
\hline & & & & \\
\hline & & & & \\
\hline & & & & \\
\hline & & & & \\
\hline & & & & \\
\hline & & & & \\
\hline & & & & \\
\hline & & & & \\
\hline & & & & \\
\hline & & & & \\
\hline & & & & \\
\hline & & & & \\
\hline & & & & \\
\hline & & & & \\
\hline & & & & \\
\hline & & & & \\
\hline
\end{tabular}

- List the demonstrations, talks, exhibits, newspaper articles, tours, workshops, camps, judging events, and field trips that were a part of your dairy project experience.

- Level: Club, County, District, State, Regional, or National. 


\section{Citizenship and Community Service}

\begin{tabular}{|c|c|c|c|c|}
\hline Date & Activity & Level* & $\begin{array}{c}\text { Number of Times } \\
\text { Attended }\end{array}$ & Comments \\
\hline & & & & \\
\hline & & & & \\
\hline & & & & \\
\hline & & & & \\
\hline & & & & \\
\hline & & & & \\
\hline & & & & \\
\hline & & & & \\
\hline & & & & \\
\hline & & & & \\
\hline & & & & \\
\hline & & & & \\
\hline & & & & \\
\hline & & & & \\
\hline & & & & \\
\hline
\end{tabular}

- List your citizenship and community service accomplishments.

- Level: Club, County, District, State, Regional, or National. 


\section{Leadership Accomplishments}

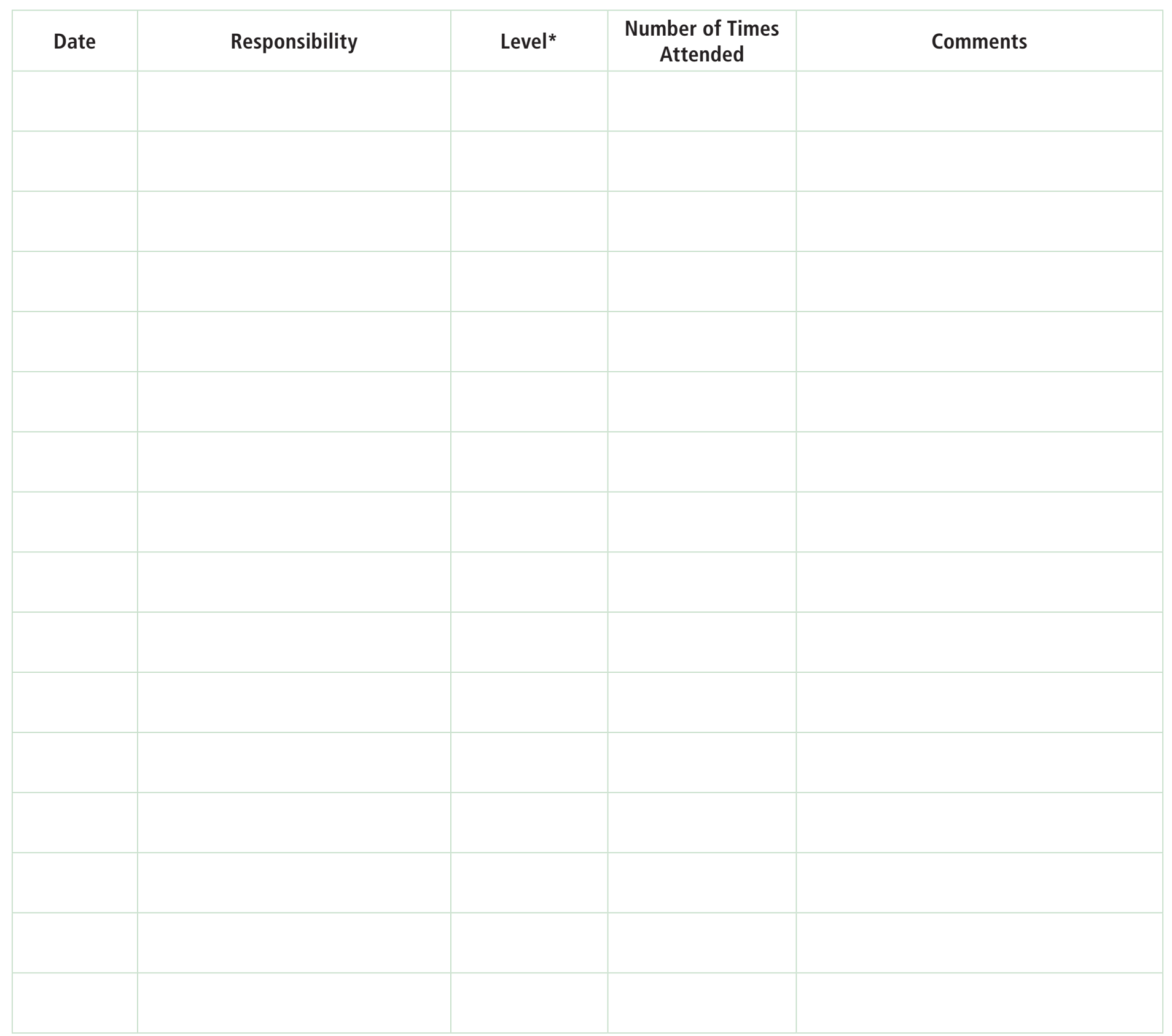

- Enter any leadership responsibilities you had during this project (e.g., committee assignments, officer positions, leading group activities, etc.)

- Level: Club, County, District, State, Regional, or National. 


\section{What skills and knowledge have you gained from this project?}

- Be specific when listing skills and knowledge gained.

- For example, instead of writing "sportsmanship," write "learned types of questions judges ask during sportsmanship and researched answers." 


\section{Project Pictures}

Pictures should show the beginning and end of your project as well as skills you learned. There should be five to eight pictures. Include a caption with each photo. The caption should tell a story and explain what you are doing and why you are doing the things shown in the photo. Pay attention to spelling and grammar. 


\section{Project Pictures Cont.}




\section{Project Story}

Write an essay about your dairy project experience.

Juniors write a minimum of 100 words. Intermediates write a minimum of 150 words. Seniors write a minimum of 250 words.

Ideas to help you:

- What have you learned?

- What safety practices have you used in your project?

- How have you managed your project?

- What can you do to improve your project next year?

- What did you do to make the best better?

- What goals did you have and how did you accomplish them?

- What workshops or clinics have you attended and what did you learn?

- How can the experiences you have had in this project help you in the future? 


\section{Appendix A: Growth Charts}

Suggested Weights and Heights for Breeding Age Heifers

\begin{tabular}{|l|c|c|c|}
\hline \multicolumn{1}{|c|}{ Breed } & $\begin{array}{c}\text { Body Weight } \\
\text { (pounds) }\end{array}$ & $\begin{array}{c}\text { Wither Height } \\
\text { (inches) }\end{array}$ & $\begin{array}{c}\text { Hip Height } \\
\text { (inches) }\end{array}$ \\
\hline Jersey & $525-575$ & $43-45$ & $45-47$ \\
\hline Ayrshire & $700-750$ & $46-48$ & $48-50$ \\
\hline Guernsey & $700-750$ & $46-49$ & $48-51$ \\
\hline Milking Shorthorn & $750-800$ & $46-48$ & $48-50$ \\
\hline Holstein & $750-800$ & $48-50$ & $50-52$ \\
\hline Brown Swiss & $750-800$ & $48-51$ & $50-53$ \\
\hline
\end{tabular}

Chart from “Monitoring Dairy Heifer Growth” Penn State College of Agricultural Sciences.

Range of Recommended Jersey Heifer Weights and Heights

\begin{tabular}{|c|c|c|}
\hline $\begin{array}{c}\text { Age } \\
\text { (months) }\end{array}$ & $\begin{array}{l}\text { Weight } \\
\text { (pounds) }\end{array}$ & $\begin{array}{l}\text { Height } \\
\text { (inches) }\end{array}$ \\
\hline 1 & $93-108$ & $29-32$ \\
\hline 2 & $122-146$ & $30-33$ \\
\hline 3 & $155-177$ & $32-34$ \\
\hline 4 & $183-217$ & $34-36$ \\
\hline 5 & $233-278$ & $35-38$ \\
\hline 6 & $259-321$ & $36-39$ \\
\hline 7 & $303-362$ & $38-40$ \\
\hline 8 & $335-412$ & $39-41$ \\
\hline 9 & $373-436$ & $40-42$ \\
\hline 10 & $391-483$ & $40-42$ \\
\hline 11 & $428-499$ & $41-43$ \\
\hline 12 & $471-548$ & $42-44$ \\
\hline 13 & $500-571$ & $43-45$ \\
\hline 14 & $535-602$ & $44-45$ \\
\hline 15 & $565-640$ & $44-46$ \\
\hline 16 & $583-661$ & $45-46$ \\
\hline 17 & $609-696$ & $45-47$ \\
\hline 18 & $639-753$ & $45-47$ \\
\hline 19 & $651-769$ & $46-47$ \\
\hline 20 & $698-813$ & $46-48$ \\
\hline 21 & $719-827$ & $47-48$ \\
\hline 22 & $758-860$ & $47-49$ \\
\hline 23 & $760-878$ & $48-49$ \\
\hline 24 & $790-893$ & $48-50$ \\
\hline
\end{tabular}

Chart from “Monitoring Dairy Heifer Growth” Penn State College of Agricultural Sciences. 
Range of Recommended Holstein Heifer Weights and Heights

\begin{tabular}{|c|c|c|}
\hline $\begin{array}{c}\text { Age } \\
\text { (months) }\end{array}$ & $\begin{array}{l}\text { Weight } \\
\text { (pounds) }\end{array}$ & $\begin{array}{l}\text { Height } \\
\text { (inches) }\end{array}$ \\
\hline 1 & $130-135$ & $31-33$ \\
\hline 2 & $177-189$ & $33-35$ \\
\hline 3 & $226-244$ & $35-37$ \\
\hline 4 & $275-299$ & $36-39$ \\
\hline 5 & $323-354$ & $38-40$ \\
\hline 6 & $372-408$ & $39-42$ \\
\hline 7 & $420-463$ & $41-43$ \\
\hline 8 & $469-518$ & $42-45$ \\
\hline 9 & $518-572$ & $43-46$ \\
\hline 10 & $566-627$ & $44-47$ \\
\hline 11 & $615-682$ & $45-48$ \\
\hline 12 & $664-737$ & $46-49$ \\
\hline 13 & $712-791$ & $47-49$ \\
\hline 14 & $761-846$ & $47-50$ \\
\hline 15 & $858-956$ & $49-51$ \\
\hline 16 & $858-956$ & $49-51$ \\
\hline 17 & $931-1026$ & $50-52$ \\
\hline 18 & $956-1065$ & $50-52$ \\
\hline 19 & $1007-1086$ & $50-52$ \\
\hline 20 & $1053-1174$ & $51-53$ \\
\hline 21 & $1086-1191$ & $51-54$ \\
\hline 22 & $1150-1284$ & $51-55$ \\
\hline 23 & $1279-1300$ & $52-57$ \\
\hline 24 & $1247-1393$ & $52-57$ \\
\hline
\end{tabular}

Chart from “Monitoring Dairy Heifer Growth” Penn State College of Agricultural Sciences.
Range of Recommended Guernsey Heifer Weights and Heights

\begin{tabular}{|c|c|c|}
\hline $\begin{array}{c}\text { Age } \\
\text { (months) }\end{array}$ & $\begin{array}{l}\text { Weight } \\
\text { (pounds) }\end{array}$ & $\begin{array}{l}\text { Height } \\
\text { (inches) }\end{array}$ \\
\hline 1 & $122-143$ & $31-33$ \\
\hline 2 & $166-193$ & $33-35$ \\
\hline 3 & $203-233$ & $35-37$ \\
\hline 4 & $255-299$ & $37-38$ \\
\hline 5 & $299-354$ & $38-41$ \\
\hline 6 & $366-434$ & $40-42$ \\
\hline 7 & $384-448$ & $41-43$ \\
\hline 8 & $433-503$ & $42-44$ \\
\hline 9 & $482-568$ & $43-47$ \\
\hline 10 & $511-588$ & $44-46$ \\
\hline 11 & $574-662$ & $45-47$ \\
\hline 12 & $576-674$ & $46-48$ \\
\hline 13 & $643-756$ & $46-48$ \\
\hline 14 & $696-803$ & $47-49$ \\
\hline 15 & $740-866$ & $48-50$ \\
\hline 16 & $779-899$ & $49-51$ \\
\hline 17 & $830-950$ & $50-52$ \\
\hline 18 & $864-1001$ & $50-52$ \\
\hline 19 & $900-1015$ & $51-52$ \\
\hline 20 & $914-1046$ & $51-53$ \\
\hline 21 & $967-1112$ & $51-53$ \\
\hline 22 & $996-1123$ & $52-54$ \\
\hline 23 & $1025-1177$ & $52-54$ \\
\hline 24 & $1026-1178$ & $52-55$ \\
\hline
\end{tabular}

Chart from "Monitoring Dairy Heifer Growth" Penn State College of Agricultural Sciences. 
Range of Recommended Ayrshire Heifer Weights and Heights

\begin{tabular}{|c|c|c|}
\hline $\begin{array}{c}\text { Age } \\
\text { (months) }\end{array}$ & $\begin{array}{l}\text { Weight } \\
\text { (pounds) }\end{array}$ & $\begin{array}{l}\text { Height } \\
\text { (inches) }\end{array}$ \\
\hline 1 & $131-154$ & $31-32$ \\
\hline 2 & $177-205$ & $32-34$ \\
\hline 3 & $223-256$ & $34-36$ \\
\hline 4 & $269-307$ & $36-38$ \\
\hline 5 & $315-357$ & $37-39$ \\
\hline 6 & $360-407$ & $39-41$ \\
\hline 7 & $405-457$ & $40-42$ \\
\hline 8 & $450-506$ & $41-43$ \\
\hline 9 & $494-554$ & $42-44$ \\
\hline 10 & $538-602$ & $43-45$ \\
\hline 11 & $581-650$ & $44-46$ \\
\hline 12 & $624-697$ & $45-47$ \\
\hline 13 & $666-743$ & $46-48$ \\
\hline 14 & $707-789$ & $46-48$ \\
\hline 15 & $748-834$ & $47-49$ \\
\hline 16 & $787-878$ & $48-49$ \\
\hline 17 & $826-922$ & $48-50$ \\
\hline 18 & $864-965$ & $48-50$ \\
\hline 19 & $901-1007$ & $49-50$ \\
\hline 20 & $937-1049$ & $49-51$ \\
\hline 21 & $972-1089$ & $49-51$ \\
\hline 22 & $1006-1129$ & $50-52$ \\
\hline 23 & $1039-1168$ & $50-52$ \\
\hline 24 & $1070-1206$ & $50-52$ \\
\hline 25 & $1101-1244$ & $51-53$ \\
\hline
\end{tabular}

Chart from "Monitoring Dairy Heifer Growth" Penn State College of Agricultural Sciences.
Range of Recommended Brown Swiss Heifer Weights and Heights

\begin{tabular}{|c|c|c|}
\hline $\begin{array}{c}\text { Age } \\
\text { (months) }\end{array}$ & $\begin{array}{l}\text { Weight } \\
\text { (pounds) }\end{array}$ & $\begin{array}{l}\text { Height } \\
\text { (inches) }\end{array}$ \\
\hline 1 & $134-163$ & $32-34$ \\
\hline 2 & $187-223$ & $34-36$ \\
\hline 3 & $240-283$ & $36-38$ \\
\hline 4 & $293-343$ & $37-40$ \\
\hline 5 & $345-403$ & $39-42$ \\
\hline 6 & $396-462$ & $40-44$ \\
\hline 7 & $447-521$ & $42-45$ \\
\hline 8 & $498-580$ & $43-46$ \\
\hline 9 & $548-637$ & $44-48$ \\
\hline 10 & $597-694$ & $45-49$ \\
\hline 11 & $645-750$ & $46-50$ \\
\hline 12 & $693-805$ & $47-51$ \\
\hline 13 & $739-859$ & $48-52$ \\
\hline 14 & $785-912$ & $49-52$ \\
\hline 15 & $829-963$ & $49-53$ \\
\hline 16 & $872-1013$ & $50-54$ \\
\hline 17 & $914-1061$ & $50-54$ \\
\hline 18 & $955-1107$ & $51-55$ \\
\hline 19 & $994-1152$ & $51-55$ \\
\hline 20 & $1032-1194$ & $52-56$ \\
\hline 21 & $1068-1235$ & $52-56$ \\
\hline 22 & $1103-1273$ & $52-56$ \\
\hline 23 & $1136-1309$ & $53-57$ \\
\hline 24 & $1167-1343$ & $53-57$ \\
\hline 25 & $1197-1374$ & $53-57$ \\
\hline
\end{tabular}

Chart from "Monitoring Dairy Heifer Growth" Penn State College of Agricultural Sciences. 
Range of Recommended Milking Shorthorn Heifer Weights and Heights

\begin{tabular}{|c|c|c|}
\hline $\begin{array}{c}\text { Age } \\
\text { (months) }\end{array}$ & $\begin{array}{l}\text { Weight } \\
\text { (pounds) }\end{array}$ & $\begin{array}{l}\text { Height } \\
\text { (inches) }\end{array}$ \\
\hline 1 & $128-160$ & $31-32$ \\
\hline 2 & $175-210$ & $33-34$ \\
\hline 3 & $223-262$ & $34-36$ \\
\hline 4 & $272-315$ & $36-38$ \\
\hline 5 & $320-370$ & $37-39$ \\
\hline 6 & $369-425$ & $37-41$ \\
\hline 7 & $418-482$ & $40-42$ \\
\hline 8 & $467-539$ & $41-43$ \\
\hline 9 & $515-596$ & $42-44$ \\
\hline 10 & $564-653$ & $43-45$ \\
\hline 11 & $611-709$ & $44-46$ \\
\hline 12 & $658-765$ & $45-47$ \\
\hline 13 & $705-820$ & $46-47$ \\
\hline 14 & $750-874$ & $46-48$ \\
\hline 15 & $794-926$ & $47-49$ \\
\hline 16 & $838-977$ & $47-49$ \\
\hline 17 & $880-1025$ & $48-50$ \\
\hline 18 & $920-1071$ & $48-50$ \\
\hline 19 & $959-1115$ & $49-50$ \\
\hline 20 & $997-1155$ & $49-51$ \\
\hline 21 & $1033-1192$ & $49-51$ \\
\hline 22 & $1066-1226$ & $50-51$ \\
\hline 23 & $1098-1256$ & $50-52$ \\
\hline 24 & $1128-1281$ & $50-52$ \\
\hline 25 & $1155-1303$ & $51-52$ \\
\hline
\end{tabular}

Chart from "Monitoring Dairy Heifer Growth” Penn State College of Agricultural Sciences. 


\section{Appendix B: Feed Records}

Use the following information to help you complete your Feed Records page.

POUNDS OF FEED: This value represents the pounds of feed consumed by one animal on the date the feed was weighed, multiplied by the number of days in the month.

Example: 5 pounds of concentrate mix were weighed and consumed on March 5.

5 pounds $\mathrm{x} 31$ days $=155$ pounds of concentrate consumed in March

VALUE OF FEED: This figure represents the average total value of pounds of feed consumed per animal per month.

Example: If the feed cost $\$ 14.00 / 50$ pounds, and you fed 155 pounds, you would calculate the value of the feed as follows.

$(\$ 14.00 \times 155$ lbs. $) / 50$ lbs. $=\$ 43.40$

OR

$(\$ 14.00 / 50$ lbs. $)=\$ 0.28 /$ lb. $\times 155$ lbs. $=\$ 43.40$

DATE FEED WEIGHED: Select a day each month to weigh the pounds of the different types of feed consumed by your animal(s) and record this date in the appropriate column.

YEAR'S TOTAL FEED EXPENSE: This figure represents the sum of the columns of pounds of feed consumed per month and the value of the feed consumed per month.

PRICE USED PER POUND OF FEED: This figure should represent the price per pound of feed used when calculating the value of each feed ingredient.

Example: If feed costs $\$ 14.00 / 50$ lbs., the cost is $\$ 0.28 / \mathrm{lb}$. 


\section{Appendix C: Depreciation}

Depreciation is the annual reduction in value of an item due to use, wear, age, or a combination of these factors. For an item to be depreciable, it must be owned, have a useful life greater than one year, have a finite and determinable life, and have productive use in the business. In agriculture, examples of depreciable items are buildings, vehicles, machinery, equipment, fences, other land improvements, and breeding livestock. Items that are not depreciable are real estate, market livestock, crop inventories, and supplies.

Calculating depreciation is a simple process; however, it becomes complicated because items depreciate at different rates depending on use, condition, and other factors.

\section{For Juniors}

When calculating depreciation, you will use a $10 \%$ per year depreciation of the original purchase cost for the items you will still have at the end of the project. This includes items you had at the beginning of the project as well as items purchased during the current calendar year.

Example: If you purchased a grooming chute for $\$ 800.00$, the value of that chute would be $10 \%$ less at the end of the year.

$\$ 800.00 \times 0.1=\$ 80.00$

The beginning value is $\$ 800.00$ and the ending value is $\$ 720.00$.

$\$ 800.00-\$ 80.00=\$ 720.00$

For each year you own this grooming chute, it will depreciate by $\$ 80.00$.

\section{For Intermediates and Seniors}

There are three common methods of depreciation: straight line, declining balance, and sum-of-year's digits. For your record book purposes, you will use straight line depreciation. This method gives you a constant depreciation value for each year. The formula is:

(Original Cost - Salvage Value)/Useful Life

\section{Some terms to know:}

Original Cost: The price paid for the item.

Salvage Value: Expected market value of the item at the end of 5 years.

Useful Life: Number of years the item is expected to be used.

\section{What is an item's useful life?}

5 years: Vehicles, purchased breeding cattle, computers

7 years: Most farm machinery and equipment, fences

10 years: Single-purpose structures

20 years: General purpose buildings 
Example: If you purchased a grooming chute for $\$ 800.00$ with a salvage value of $\$ 400.00$ and a useful life of 7 years, you would calculate the depreciation as follows.

$(\$ 800.00-\$ 400.00) / 7$ years $=\$ 57.14 /$ year

With straight line depreciation the annual depreciation for the grooming chute would be $\$ 57.14$ each year. 